\title{
Culinary Experience Towards Behavioral Intention Of Domestic Tourists in Solo and Bandung, Indonesia
}

\author{
Monika Kristanti ${ }^{1}$, Regina Jokom ${ }^{2}$ Serli Wijaya ${ }^{3}$, and Deborah C. Widjaja ${ }^{4}$ \\ 1, 2, 4 Hotel Management Department, Petra Christian University \\ ${ }^{3}$ Master Program in Management, Petra Christian University \\ Email: mkrist@petra.ac.id
}

\begin{abstract}
Solo and Bandung are two of the five major gastronomic destinations in Indonesia that are chosen by the Ministry of Tourism and Creative Economy. This research aimed to evaluate the effects of culinary experience quality towards behavioral intention through culinary experience satisfaction and destination experience satisfaction. A questionnaire involving 200 domestic tourists was completed and analyzed by using PLS path modelling. The findings indicate that culinary experience quality significantly influences culinary experience satisfaction, however it will not significantly influence the satisfaction from destination experience. Moreover, it is also found that culinary experience satisfaction in Solo and Bandung does not have a significant effect on destination experience satisfaction. In addition, destination experience satisfaction has a positive and significant impact on domestic tourist's behavioral intention, while, culinary experience satisfaction does not significantly influence their behavioral intention.

Keywords: Culinary Experience Quality, Culinary experience satisfaction, Destination experience satisfaction, Tourist's Behavioral intention.
\end{abstract}

JEL : M14

DOI : 10.24002/kinerja.v22i2.1813

Received : 22-09-2018 Reviewed: 17-10-2018 Final Version: 19-10-2018

\section{INTRODUCTION}

The richness of natural resources and culture in each area lead to the growth of culinary tourism in Indonesia. There are 485 ethnics in Indonesia that have local food with their own characteristics or uniqueness (Yurnaldi, 2010). Local and yet authentic food can be used to promote the destination and acted as a differentiate 
tool from one destination to another, so it can create such unique attraction for domestic and international tourist, to visit a destination (Mak et al., 2012).

In the last few years, the Indonesian government contributes great support for the development of culinary tourism. In 2015, the Ministry of Tourism and Creative Economy has designate five major gastronomic destinations in Indonesia. They are Bali, Yogyakarta, Bandung, Solo and Semarang (Ministry of Tourism and Creative Economy of the Republic of Indonesia, 2015).

Bandung has become one of the iconic Indonesian tourism called Paris van Java, and got the first place of Indonesia's Attractiveness Award 2017 (Fakrulloh, 2017). The culture of Bandung is affected by lots of aspects, the Tarumanegara relics and colonization by Japan, Portugal and Netherlands, that create a unique fusion of culture (Fathoni, 2013). The culinary fusion, the unique and distinctive taste of food, and the unique way of food consumption make Bandung as one of the tourism destination. The culinary tourism of Solo becomes one of the best gastronomic destinations in Indonesia that able to attract domestic and international tourists (Solopos.com, 2016). The traditional culinary of Solo are timlo, serabi, and nasi liwet that have a sweet taste because of the use of sugar palm and sweet soya sauce.

Studies by Björk and Kauppinen-Räisänen (2014) and Kivela and Crotts (2006) emphasized the importance of understanding the relationship between food and tourism; there is a relationship between culinary experience and satisfaction of tourists, the culinary experience satisfaction and the destination experience satisfaction (Pestek and Cinjarevic, 2014). A tourist's experience of local culinary of the visited destinations influences the overall travel experience (Hendijani, 2016). An impressive and unforgettable culinary experience can also trigger the branding of the destination and most importantly, contribute to the overall satisfaction of tourists. There is also a positive significant relationship between food image and intention to visit a destination (Karim and Chi, 2010). The destination experience satisfaction affects the behavioral intention of tourists. The satisfied tourists tend to visit the same destination and give positive word-of-mouth (Roozbeh et al., 2012).

According to the authors' knowledge, not much research has been done in terms of the relationship between the culinary experience quality, the culinary experience satisfaction, the destination experience satisfaction, and the behavioral intention in Bandung and Solo. Therefore, the authors are addressed to analyze more deeply about how the culinary experience quality of domestic tourists in Bandung and Solo could affect the behavioral intention. This will be very much beneficial for the local government to develop local culinary in Bandung and Solo that will give culinary experience for the domestic tourists.

The aims of the study are four folds namely:

1. to examine the effect of culinary experience quality on culinary experience satisfaction. 
2. to investigate the effect of culinary experience satisfaction on the destination experience satisfaction.

3. to observe the effect of culinary experience quality on the destination experience satisfaction.

4. to examine the effect of culinary experience satisfaction and the destination experience satisfaction on the behavioral intention

\section{LITERATURE REVIEW}

\subsection{Culinary Experience Quality}

Hendijani (2016) suggested that by consuming local foods, tourist can conceive the identities and ethnicities of people of a given destination. In terms of cultural point of view, food experience portrays the images of cultural experience, status and cultural identity. Such cultural aspect is usually developed from the unique aspects of food experiences that can only be attained in that particular destination. Therefore, food is something that is deeply rooted in the culture and traditions of a region. Experiencing local foods on vacation is a type of pleasurable sensory experience (Kivela and Crotts, 2006). Foods also provide sensory experiences that enhance the pleasure of a vacation and attract tourists to a destination

Many studies have shown that there is an increase in the search for new experiences for consumers (Wang, 2016). While on vacation, tourist will tend to look after new experiences which are never been achieved before, including enjoying traditional, authentic, unique and new food (Björk and KauppinenRäisänen, 2013). A variety of food-related characteristics such as preparation, cooking style, presentation, dining customs, food culture, and food consumption can be included to construct experiences that tourist has with food at the destination. Culinary experience is not only influenced by traditional food, but also can be influenced by social aspect, external environment, and services provide in a particular destination (Björk and Kauppinen-Räisänen, 2013). Thus, each of these aspects can make a memorable trip for tourists. The sensory aspects of food enable tourists to experience the culture of a particular country on a deeper level (Hendijani, 2016).

Björk and Kauppinen-Räisänen (2014) explains that the culinary experience refers to the process in which each experience occurs in various stages, ie before experience (eg, searching for a restaurant or food), during experience (eg, meal experience) and after the experience of eating (eg, the purchasing the local food as souvenirs. It should also be noted that the culinary experience is something subjective, meaning that the culinary experience is influenced by the individual's own experience. 
Tourist destinations in this modern era can employ culinary as a representative of cultural experience, status, cultural identity, as well as how to communicate the tourist destinations (Hendijani et al.,2013). Further, Karim and Chi (2010) also said that food can reveal a unique and pleasurable experience for tourists. In particular, food can fully add to the tourist experience and could be the most memorable part of the trip.

\subsection{Tourist Satisfaction}

Many researchers have identified that food experience at a destination can represent an important source of satisfaction for tourists (Hendijani, 2016). Hendijani (2016) also found that food has a significant result on tourists' overall satisfaction with the trip. Thus, suggested that a new food experience brings excitement to people's lives, and this experience is considered a means of improving oneself when expectation and satisfaction are combined. Kivela and Crotts (2009) mentioned that food can increase value to the tourist experience and is associated with tourism quality for tourists in search of new experiences that yield a high level of satisfaction. In general, it seems that food significantly contributes to tourists' overall satisfaction.

Before going on vacation to a particular destination, tourist will have an expectation or image about the particular destination that has been chosen, which can be influenced by their own minds, beliefs, and opinions. Thus, if the experience achieved meets the expectations, then tourist will feel fulfilled which conducted in satisfaction forms. Satisfaction born as a result of tourist' assessment based on experiences they have been through (Sukiman et al., 2013). Sanchez-Cañizares and Castillo-Canalejo (2015) identified satisfaction as a tourist' feeling after the consumption of products or services by comparing the performance of products/services received with the expectations. Satisfaction is also defined as the consumer's judgment on whether the product/service provides satisfactionrelated levels of consumption.

The provision and quality of elements such as attractions, public and private facilities, accessibility, human resources, image and character, also price can impact on shaping the experience, satisfaction, and also the decision of tourists to travel (World Tourism Organization, 2007). Sukiman et al. (2013) also said that tourist satisfaction can be influenced by the quality of the products (presentation, taste, smell) and the quality of service (place, easy access, friendly staff), which then need tourist emotional reaction as an assessment. The satisfaction of a group of tourist and service facilities in a location is the benchmark for the satisfaction of tourist destinations (Wang, 2016). 
The results of Roozbeh et al. (2012) suggests that food is an important and interesting thing to add to the attraction of a tourist destination. Furthermore, in the study of Roozbeh et al. (2012), a positive perception of the food experience among first-time travelers and repeat visitors of a tourist destination suggests that satisfaction from local food can be used to emerge tourist satisfaction and trigger repeated travel intentions for future ahead.

\subsection{Tourist Behaviour Intention}

Individuals behavioral intentions sometimes can be viewed by the willingness to use again something that has been used before, to go back to a place where has been visited before, to feel again services that have been enjoyed before, or willingness to share positive informations about a place or a thing to families or acquaintances. This is the result of overall tourist satisfaction (Amoah et al., 2016). Rajaratnam et al (2015) also said that culinary experience demand such emotional response from tourist which will affect towards tourist behavior intentions in the future ahead. Prayag et al. (2013), then suggested that there is a significant relation between tourist satisfaction and behavior intentions.

Behavioral intentions often stem from structured decision making which go through the processes of selecting, deliveingr, and using products, services, experiences, or ideas in satisfying needs and desires (Roozbeh, 2012). Consumer behavior is also related to the social and economic impacts that emerge in purchasing and consumption behavior. Altintzoglou et al., (2016) said that a satisfied tourist will tend to have the urge to tell their acquaitances or relatives about the experience they have just enjoyed in demand for their acquaitances and relatives wanting to have the exact same experience. Sometimes, a positive emotion from tourist leaves a positive memory toward a particular destination which then lead the tourist to revisit the place to have the same feeling once again.

Many studies have examined the relationship between variables that affect consumer behavior intentions. Tourist behavior has now focused on tourist satisfaction, as tourist satisfaction influences the decision of tourists to return (Rajaratnam et al, 2015). One of the triggers of consumer behavior (in this case tourists) is the satisfaction of tourists to destinations and culinary (Peštek and Činjarević, 2014; Rajaratnam et al, 2015).

\subsection{The Relationship between Culinary Experience Quality, Tourist Satisfaction, and Behaviour Intention}

Culinary is one component of tourism products which plays an important role in creating an impressive tourist experience (Peštek and Činjarević, 2014). A tourist who has a strong desire to consume traditional foods, will also looking for impressive new culinary experiences (Björk dan Kauppinen-Räisänen, 2014). In addition, Peštek and Činjarević (2014) explained that the culinary experience is a combination of tourist's opinions, the attributes of food, and the response of tourists that involves their feelings. The response is an evaluation of the whole culinary 
experience, that will assess whether it is good or not. Based on the above explanation, the culinary experience is considered as a phenomenon that not only involves food as a whole but also includes emotions from tourists. The following hypothesis was deducted from the earlier study.

Hypotheses 1: Culinary experience quality (CEQ) has a positive and significant impact on culinary experience satisfaction (CES)

Culinary has a role as a national identity. Whereas, culinary will help to present the identity and culture of a destination, and also create perception and opinion about the building views, and destination images (Karim and Chi, 2010). Therefore, Bjork and Raisanen (2013) explained that food plays important role in creating the satisfaction of tourists to a destination. Hence the hypothesis appears as follows:

Hypotheses 2: Culinary experience satisfaction (CES) has a positive and significant impact on the destination experience satisfaction (DES)

Karim and Chi (2010) stated that food and destinations are inseparable and food can influence the tourist's destination decision. Food is also regarded as a cultural identifier of a destination (Peštek and Činjarević, 2014). In addition, research by Hendijani et al. (2013) also confirmed that in Malaysia, food plays an important and interesting role in enhancing destination experience. A positive culinary experience quality perceived by tourists specifically the first-time travelers indicates culinary satisfaction, which in turn, can be used to trigger revisit intention. World Tourism Organization (2007) stated that the culinary experience is one of the attraction factors, which is able to encourage the satisfaction of tourists to a destination. Based on the above discussion, the following hypothesis was proposed as:

Hypotheses 3: Culinary experience quality has a positive and significant impact on the destination satisfaction

In addition, Destination management organizations (DMOs) could utilize culinary as a representative of cultural experience, status, cultural identity, as well as how to communicate the tourist destinations (Horng et al, 2012). Further, Silkes et al. (2013) noted that food could show a unique and most memorable experience of the whole trip. Therefore, Hendijani et al. (2013) showed that food could give additional attraction to the destination. Moreover, destination satisfaction does not only trigger the repeated selection of a tourist destination but also affect the tourist's behavior intentions as a whole (Rajaratnam and Nair, 2015). This statement is supported by research from Huang \& Hsu (2009) quoted from Björk and Räisänen (2013) which states that travelers apply the memory of the tourist experience in determining travel intentions (for example, the option to re-visit a tourist attraction or re-repeat an experience). Furthermore, Roozbeh et al. (2012) also explain that local food can be used to drive tourism products and trigger repeated travel intentions in a tourist destination. Hence the hypothesis appears as follows: 
Hypotheses 4: Culinary experience satisfaction and destination experience satisfaction has a positive and significant impact on tourist's behavioral intention

Hypotheses 4a: Culinary experience satisfaction (CES) has a positive and significant impact on tourist's behavioral intention (BI)

Hypotheses 4b: Destination experience satisfaction (DES) has a positive and significant impact on tourist's behavioral intention (BI)

Based on the literature review, the research model is presented in figure 1

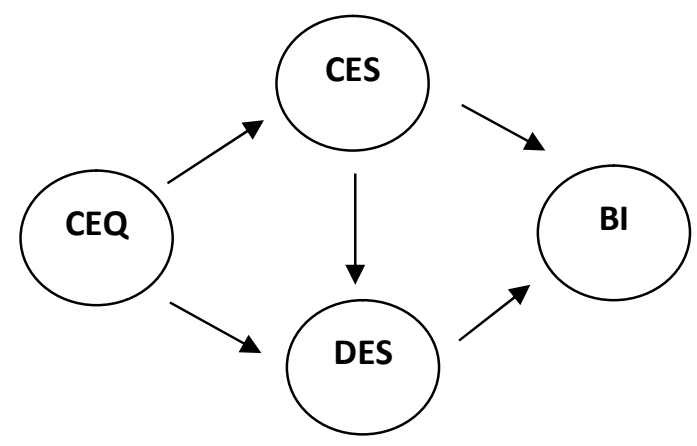

Figure 1. Research Model

\section{METHODOLOGY}

\subsection{Survey Instrument and Sample}

The data were collected through self-administered questionnaire-based survey to domestic tourists who have been visited Bandung and Solo. The sampling process used was judgemental sampling that the respondents should be at least 21 years, and have enjoyed local food during their visit to Bandung and Solo.

The questionnaire was divided into several parts. Part 1 sought information about participant demographics such as gender, age, occupation, the purpose of visit and the length of stay. Part 2 contained questions related to the culinary experience quality of domestic tourists in Bandung and Solo. In Part 3, the participants were requested to give opinions regarding culinary experience satisfaction in Bandung and Solo. Part 4 sought participants' opinions regarding their visited destination experience satisfaction, and part 5 contained questions related to behavioral intention of domestic tourists.

The culinary experience quality was measured by three sub-variables, namely food, social and place, and there were adapted from Björk dan KauppinenRäisänen (2014). The culinary experience satisfaction were translated to overall satisfaction to food, social interaction and quality of place, which were adapted from Kivela and Crotts (2006); and the destination experience satisfaction was measured by four sub-variables, namely attraction, public and private facilities, human resources, and price, which were adapted from Wang (2016). The 
behavioral intention was measured by two sub-variables. Those variables are revisit intention and recommendation intention, that were adapted from Karim dan Chi (2010) and Rajaratnam et al. (2015). The level of agreement with given statements was assessed by using a seven-point Likert-type scale, with anchors "strongly disagree" as 1 and "strongly agree" as 7.

\subsection{Preliminary Data Analysis}

A total of 200 questionnaires distributed to domestic tourists in Bandung and Solo. Prior to data analysis employing the above-mentioned statistical techniques, the data-cleaning process was accomplished to test the normality and possible outliers. One questionnaire was identified as an outlier, leaving a total of 199 usable questionnaires ready for further data analysis. The study employed descriptive statistics to describe the participants' profiles meanwhile Partial Least Square (PLS) path modeling was applied to test the proposed research hypotheses.

\section{RESULT AND DISCUSSION}

\subsection{Profile of participants}

Of all the respondents, $53.3 \%$ were male and $46.7 \%$ were female. The majority of the participants were between 21 and 30 years old (58.8\%) and mostly from Jakarta and Surabaya $(40.2 \%)$. Two major occupations are students and entrepreneur which at about $66.8 \%$ of total participants. In terms of the participants' traveling behavior, the majority of participants visit Bandung and Solo for leisure $(40.7 \%)$, already visited the destination more than 3 times $(49.2 \%)$, together with family or friends $(76.4 \%)$, and stayed for less than a week $(59.3 \%)$.

\subsection{Result}

PLS path analysis was employed to assess the research model and test the proposed hypotheses. the validity and reliability levels of the observable variables were good, which had loading factors above 0.50, except CEQ6 which is about enjoying the interaction with the local people. Therefore, this indicator will not be used in the next calculation. This means the empirical indicators were a valid reflector of the examined latent variables, respectively. Figure 2 showed the result 


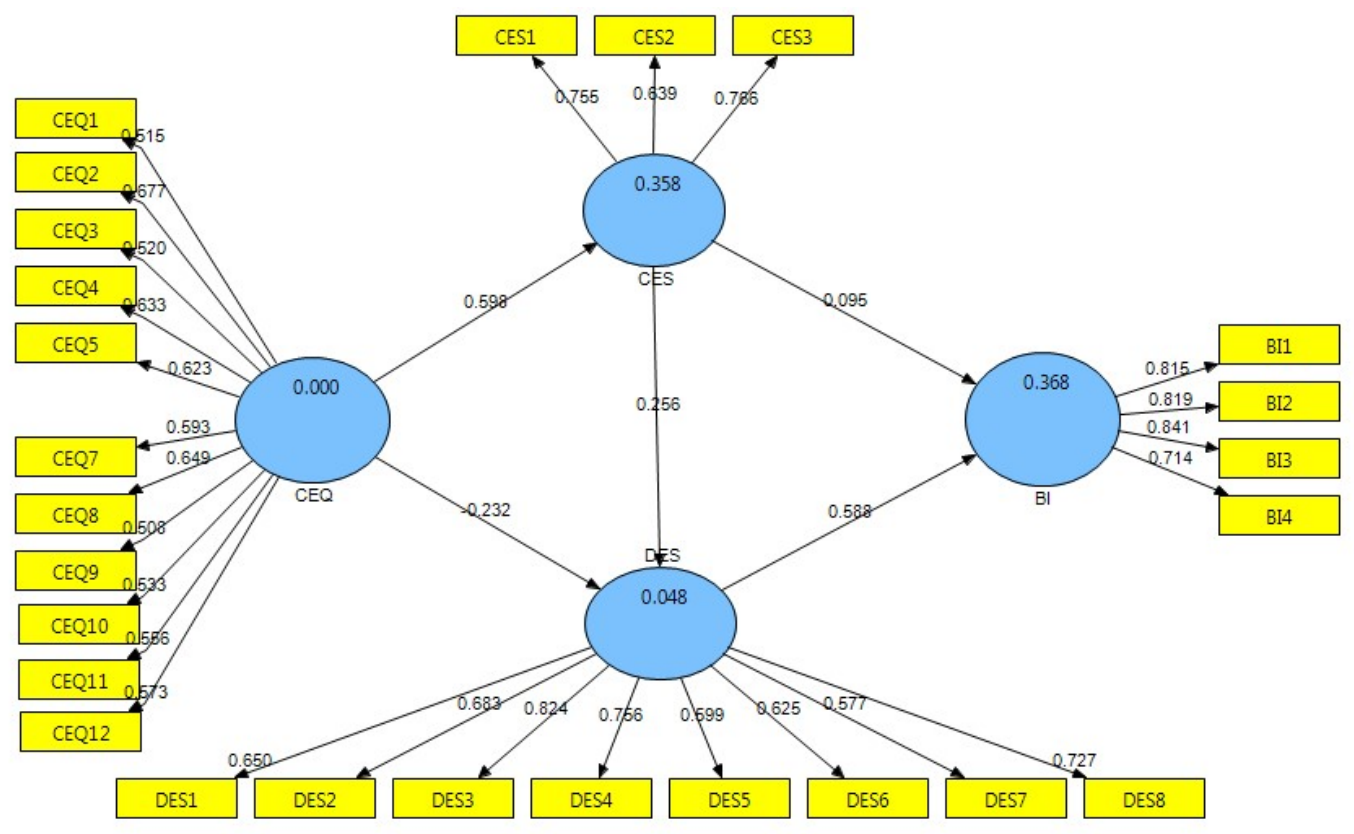

Figure 2. Path diagram of the research model

In addition, table 1 exhibits the composite reliability of three latent variables. It shows that all had the score above the cut-off value of 0.70 (reliable).

Table 1. Composite reliability of latent variables.

\begin{tabular}{ll}
\hline CEQ (Culinary Experience Quality) & 0.848713 \\
CES (Culinary Experience Satisfaction) & 0.764709 \\
DES (Destination Experience Satisfaction) & 0.874535 \\
BI (Behaviour Intention) & 0.875296 \\
\hline
\end{tabular}


The result of R-square Model is presented in Table 2. The goodness of fit in PLS can be seen from the Q2 value. The value of Q2 has the same meaning as the determination coefficient (R-square / R2) in regression analysis. The higher the $\mathrm{R} 2$, the more fit the model with the data. From the $\mathrm{R} 2$ values, the $\mathrm{Q}$ value can be calculated as follow: $\mathrm{Q} 2=1-[(1-0.357889) \times(1-0.048225) \times(1-0.0 .368144]=$ $61.38 \%$.

Table 2. The R Square result

\begin{tabular}{ll}
\hline CEQ (Culinary Experience Quality) & - \\
CES (Culinary Experience Satisfaction) & 0.357889 \\
DES (Destination Experience Satisfaction) & 0.048225 \\
BI (Behaviour Intention) & 0.368144 \\
\hline
\end{tabular}

Moreover, the subsequent path analysis revealed the result of the inner weights. Table 3 shows that the relationship among the variables was majority positive (original sample estimate). From the result of the t-statistics, it revealed that mostly the relationships are not significant, therefore only the hypotheses 1 are accepted.

Table 3. Inner weight result

\begin{tabular}{l|l|l|l|l|l}
\hline & $\begin{array}{l}\text { Original } \\
\text { Sample } \\
(\mathrm{O})\end{array}$ & $\begin{array}{l}\text { Sample } \\
\text { Mean }(\mathrm{M})\end{array}$ & $\begin{array}{l}\text { Standard } \\
\text { Deviation } \\
(\text { STDEV) }\end{array}$ & $\begin{array}{l}\text { Standard } \\
\text { Error } \\
(\text { STERR) }\end{array}$ & $\begin{array}{l}\text { T-Statistic } \\
(\text { IO/STERRI) }\end{array}$ \\
\hline CEQ -> CES & 0.598238 & 0.613327 & 0.071275 & 0.071275 & 8.393397 \\
CEQ -> DES & -0.232014 & -0.238142 & 0.121512 & 0.121512 & 1.909393 \\
CES -> DES & 0.255673 & 0.261414 & 0.128145 & 0.128145 & 1.995179 \\
CES -> BI & 0.095290 & 0.094438 & 0.082251 & 0.082251 & 1.158529 \\
DES -> BI & 0.588186 & 0.598031 & 0.068397 & 0.068397 & 8.599548 \\
\hline
\end{tabular}

The result of the model is shown in figure 3

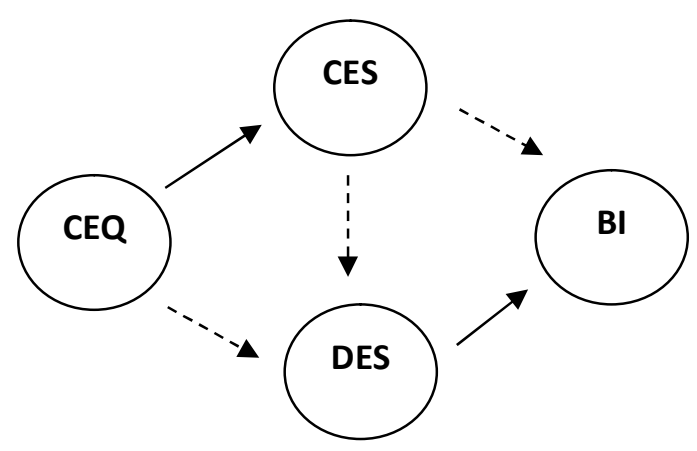




\section{$\longrightarrow$ Significant \\ $-\ldots$ Not Significant}

Figure 3. The Result of the Model

\subsection{Discussion}

\subsubsection{The Effect of Culinary Experience Quality on Culinary Satisfaction}

Based on the data analysis, it was proven that culinary experience quality (CEQ) significantly influenced the culinary experience satisfaction (CES). It means that the higher the quality of the culinary experience as perceived by the respondents, the higher the satisfaction of the culinary experience.

The three indicators that contributed most to the culinary experience quality were the authenticity of taste and spices of local food, the different way of eating compared to tourists' place, and the unique cooking method. It can be seen that the local food of Bandung uses lots of garlic, onion, and spices such as candlenut, coriander, and galangal. One of the examples of local food in Bandung that has authentic taste and unique cooking method is empal gepuk. As for Solo, the taste of the local food is tend to be sweet because of the use of brown sugar and sweet soy sauce, and the examples of the local food are timlo solo, serabi, and nasi liwet.

Based on the above explanation, this finding is in accordance with the previous studies by Roozbeh et al (2012), satisfaction to the authenticity of taste and method of cooking can increase the culinary experience satisfaction. It also supports the previous research by Peštek and Činjarević (2014) that local food influences culinary satisfaction. It is also in line with Kivela and Crotts (2006) that culinary experience add value to the tourism experience for tourists who seek new experiences and culinary experience which will bring satisfaction.

\subsubsection{The Effect of Culinary Satisfaction on The Destination Satisfaction}

Based on the result, it can be seen that culinary experience satisfaction (CES) is not significantly influenced by the destination experience satisfaction (DES). This finding is not in accordance with the previous studies by Kivela and Crotts (2006), and Roozbeh et al (2012). They stated that culinary experience is one of the important variables for tourists in creating destination experience satisfaction. 
In this research, CES is not significantly influenced DES because the tourists are domestic tourists that mostly come from Jakarta and Surabaya. While the tourists are in Bandung and Solo, they tend to go to tourism places and not to experience local food. According to Björk and Kauppinen-Räisänen (2013), international tourists tend to explore something they cannot find in their home country. In this research, the respondents are domestic tourists who can find local food of Bandung and Solo in their own city including the authentic taste and method of serving. So that the domestic tourists will choose to go to touristic places and pay intention to the infrastructure of Bandung and Solo.

\subsubsection{The Effect of Culinary Experience Quality on The Destination Satisfaction}

According to the T-statistic score, culinary experience quality does not impact significantly on destination experience satisfaction, therefore the hypotheses 3 is rejected. It might be explained by looking at each main reflector. Figure 2 showed that the main reflector of culinary experience quality is CEQ2 which is the authentic taste and uses authentic spices, while, the main reflector of destination experience satisfaction is DES3 which is the quality of tourism infrastructure (local transport, telecommunication etc). It indicates that domestic tourists tend to measure the culinary experience quality from the taste, and the destination experience satisfaction is determined by the infrastructure. Therefore, there is no strong relationship between the food taste and the city's infrastructure. Even though the domestic tourists experience great taste of traditional food in Bandung and Solo, but it will not significantly affect their satisfaction towards the infrastructure.

\subsubsection{The Effect of Culinary Satisfaction And The Destination Satisfaction on The Behavioral Intention}

The result revealed that culinary experience satisfaction does not significantly influence domestic tourists' behavior intention, whereas, destination experience satisfaction has a positive and significant impact on domestic tourists' behavior intention. Therefore, the hypotheses 4 is rejected. Domestic tourist behavioral intention influenced more by destination experience satisfaction compared to culinary experience satisfaction, which they are considered more on the destination aspect than the traditional culinary in order to revisit Bandung and Solo. A research conducted by Pratminingsih, Rudatin, Rimenta (2014) also supported this finding, their previous research on evaluating the relationship among satisfaction, and revisiting intention revealed that satisfaction has direct impact on the revisit intention. A tourist who are satisfied with the destination will revisit the destination in the future.

\section{CONCLUSION}

This study has been assessed the effect of culinary experience quality on behavior Intention of domestic tourist through culinary experience satisfaction and 
destination experience satisfaction. The findings showed that culinary experience quality significantly influences culinary experience satisfaction, however it does not significantly influence on the destination experience satisfaction. Moreover, it is also found that culinary experience satisfaction in Solo and Bandung does not have a significant effect on destination experience satisfaction. In addition, destination experience satisfaction has a positive and significant impact on domestic tourist's behavioral intention, while, culinary experience satisfaction does not significantly influence their behavioral intention.

Understanding this model will help the local government to increase the satisfaction of domestic tourist toward local culinary and the destination, in order to attract them to revisit Bandung and Solo. Moreover, the government should pay attention to the local food in Bandung and Solo by enhancing the promotion strategy particulary to the domestic tourist

\section{REFERENCES}

Amoah, F., Radder, L. and van Eyk, M., 2016. Perceived experience value, satisfaction and behavioural intentions: A guesthouse experience. African Journal of Economic and Management Studies, 7(3), pp.419-433.

Björk, P. and Kauppinen-Räisänen, H., 2014. Exploring the multi-dimensionality of travellers' culinary-gastronomic experiences. Current Issues in Tourism, pp. 1-21.

Fakrulloh., 2017. Kota Bandung Bawa Pulang Lima Kategori Penghargaan Kota Terbaik IAI 2017. [online] Available at: http://www.pikiranrakyat.com/nasional/2017/09/30/kota-bandung-bawa-pulang-lima-kategoripenghargaan-kota-terbaik-iai-2007-410543 [Accessed 10 September 2018]

Fathoni, A., 2013. Sejarah Kerajaan Tarumanagara: Kehidupan Ekonomi, Politik, dan Sosial \& Budaya. [online] Available at: http://www.zonasiswa.com/2014/05/sejarah-kerajaan-tarumanagara.html [Accessed 11 September 2018]

Hendijani, R. B., Ng, S. I. and Boo, H. C., 2013. Effect of food experience on overall satisfaction: Comparison between first-time and repeat visitors to Malaysia. International Food Research Journal, 20, 141.

Hendijani, R. B. 2016. Effect of food experience on tourist satisfaction: the case of Indonesia. International Journal of Culture, Tourism and Hospitality Research, 10(3), pp.272-282.

Horng, J.S., Liu, C.H., Chou, H.Y. and Tsai, C.Y., 2012. Understanding the impact of culinary brand equity and destination familiarity on travel intentions. Tourism management, 33(4), pp.815-824. 
Karim, S. A. and Chi, C. G.-Q., 2010. Culinary tourism as destination attraction: An empirical examination of destinations' food image. Journal of Hospitality Marketing \& Management, 19, pp. 531-555.

Kivela, J. and Crotts, J. C., 2006. Tourism and gastronomy: Gastronomy's influence on how tourists experience a destination. Journal of Hospitality \& Tourism Research, 30, pp. 354-377.

Mak, A. H., Lumbers, M., Eves, A. and Chang, R. C., 2012. Factors influencing tourist food consumption. International Journal of Hospitality Management, 31, pp. 928-936.

Ministry of Tourism and Creative Economy of the Republic of Indonesia, 2015. Siaran pers dialog gastronomi nasional dan peluncuran 5 destinasi wisata kuliner unggulan $2015 . \quad$ [online] Available at: http://www.kemenpar.go.id/asp/detil.asp?c=16\&id=3024. [Accessed 10 September 2018]

Pratminingsih, S.A., Rudatin, C.L. and Rimenta, T., 2014. Roles of motivation and destination image in predicting tourist revisit intention: A case of BandungIndonesia. International Journal of Innovation, Management and Technology, 5(1), p.19

Prayag, G., Hosany, S. and Odeh, K., 2013. The role of tourists' emotional experiences and satisfaction in understanding behavioral intentions. Journal of Destination Marketing \& Management, 2(2), pp.118-127.

Peštek, A. and Činjarević, M., 2014. Tourist perceived image of local cuisine: The case of Bosnian food culture. British Food Journal, 116, pp. 1821-1838.

Rajaratnam, S.D., Nair, V., Pahlevan Sharif, S. and Munikrishnan, U.T., 2015. Destination quality and tourists' behavioural intentions: rural tourist destinations in Malaysia. Worldwide Hospitality and Tourism Themes, 7(5), pp.463-472.

Roozbeh, B.H., Ng, S.I and Boo, H.C., 2012. Effect of food experience on overall satisfaction: comparison between first-time and repeat visitors to Malaysia. International Food Research Journal, 20(1), pp. 141-146.

Sanchez-Cañizares, S. and Castillo-Canalejo, A.M., 2015. A comparative study of tourist attitudes towards culinary tourism in Spain and Slovenia. British Food Journal, 117(9), pp.2387-2411.

Silkes, C.A., Cai, L.A. and Lehto, X.Y., 2013. Marketing to the culinary tourist. Journal of Travel \& Tourism Marketing, 30(4), pp.335-349.

Solopos, 2018. Jumlah Wisatawan Solo. [online] Available at: http://www.solopos.com/2018/02/05/wisata-solo-duh-jumlah-wisatawan-ke-solomenurun-pengelola-objek-wisata-diminta-berbenah-891532. [Accessed 10 September 2018] 
Sukiman, M.F., Omar, S.I., Muhibudin, M., Yussof, I. and Mohamed, B., 2013. Tourist satisfaction as the key to destination survival in Pahang. Procedia-Social and Behavioral Sciences, 91, pp.78-87.

Wang, Y., 2016. More important than ever: Measuring tourist satisfaction. Griffith Institute for Tourism, Griffith University.

World Tourism Organization, 2007. A practical guide to tourism destination management. World Tourism Organization.

Yurnaldi, 2010. Pariwisata Indonesia jauh ketinggalan (Indonesian tourism is left behind). [online] Available at: http://travel.kompas.com/read/2010/10/19/21091083/Pariwisata.Indonesia.Jauh.Ke tinggalan. [Accessed 12 September 2018] 